\title{
PENGARUH ISLAMIC QUALITY OF WORK LIFE, WORK FAMILY CONFLICT, DAN KOMPENSASI TERHADAP TURNOVER INTENTION PENGRAJIN BATIK
}

\author{
Umi Apriliyani' ${ }^{1}$, Siti Amaroh ${ }^{2}$ \\ ${ }^{1}$ Institut Agama Islam Negeri Kudus, Indonesia \\ Email: umiapriliyani08@gmail.com \\ ${ }^{2}$ Institut Agama Islam Negeri Kudus, Indonesia \\ Email: sitiamaroh@iainkudus.ac.id
}

\begin{abstract}
Abstrak
Penelitian ini bertujuan untuk menganalisis dan memahami signifikansi pengaruh Kehidupan Kerja Islam terhadap intensi turnover, signifikansi pengaruh Konflik Keluarga Kerja terhadap intensi turnover, dan signifikansi pengaruh Kompensasi terhadap intensi turnover pada pengrajin Industri Batik Tulis Bakaran di Juwana Pati . Jenis penelitian ini termasuk dalam analisis kuantitatif interpretatif. Penelitian ini menggunakan metode purposive sampling dalam menentukan sampel. Jumlah responden adalah 200 pengrajin. Metode pengumpulan data dalam penelitian ini adalah wawancara, dokumentasi, dan kuesioner. Teknik analisis data yang digunakan dalam penelitian ini adalah analisis dengan program aplikasi perangkat lunak SPSS. Hasil penelitian menunjukkan bahwa Kualitas Kehidupan Kerja Islami memiliki pengaruh positif dan signifikan terhadap intensi turnover, Konflik Keluarga Kerja memiliki pengaruh negatif dan signifikan terhadap intensi turnover, dan Kompensasi memiliki pengaruh positif dan signifikan terhadap intensi turnover.
\end{abstract}

Kata Kunci: Kualitas Kehidupan Kerja Islam, Konflik Pekerjaan Keluarga, Kompensasi, Niat Ingin Pindah Kerja.

\begin{abstract}
This study aims to analyze and understand the significance of Islamic Quality of Work Life influence on turnover intention, the significance of Work Family Conflict influence on turnover intention, and the significance of Compensation influence on turnover intention on craftsman of Industry Batik Tulis Bakaran in Juwana Pati. This type of research is included in the interpretive quantitative analysis. This research uses purposive sampling method in determining the sample. The number of respondents is 200craftsman. Methods of data collection in this study are interviews, documentation, and questionnaires. Data analysis techniques used in this study is the analysis with the SPSS software application program. The results showed that Islamic Quality of Work Life had a positive and significant influence on turnover intention, the Work family Conflict had a negative and significant influence on turnover intention, and the Compensation had a positive and significant influence on turnover intention.
\end{abstract}


Keywords: Islamic Quality of Work Life, Work Family Conflict, Compensation, Turnover Intention.

\section{PENDAHULUAN}

Perkembangan dunia bisnis di Indonesia semakin menuntut setiap organisasi atau suatu industri untuk bersaing secara ketat agar mampu mempertahankan bisnisnya. Untuk mempertahankan bisnisnya, perusahaan dapat memanfaatkan sumber daya yang tersedia dan mampu memaksimalkan kinerja secara optimal. Peningkatan kinerja dapat dilakukan oleh perusahaan dengan menggunakan strategi yang baik dalam menjalankan bisnisnya. Keberhasilan perusahaan dalam menjalankan bisnisnya tidak dapat terlepas dari faktor sumber daya manusia (Fuaidah, 2018:193).

Karyawan merupakan salah satu elemen penting dalam perusahaan karena kinerja yang dihasilkan akan berdampak pada kegiatan operasional perusahaan. Jika kinerja yang dihasilkan oleh karyawan itu rendah, dapat menjadi hambatan bagi perusahaan dalam pencapaian tujuannya. Demi pencapaian tujuan, perusahaan perlu memperhatikan setiap karyawannya agar dapat memberikan kontribusi yang baik terhadap perusahaannya. Karyawan yang tidak mendapatkan perhatian dari perusahaannya dan tidak terpenuhi kebutuhannya cenderung akan memilih untuk meninggalkan pekerjaannya (Turnover) (Fuaidah, 2018:194).

Banyaknya faktor yang melatarbelakangi turnover intention di dalam perusahaan atau suatu organisasi, maka penelitian ini memfokuskan pada faktor kualitas kehidupan kerja Islami, konflik pekerjaan-keluarga, dan sistem kompensasi.

Islamic Quality of work life merupakan gambaran kualitas hubungan personal dengan kondisi kerja secara keseluruhan. Penciptaan lingkungan kerja yang berkualitas merupakan tugas seluruh komponen yang ada di organisasi (Rokhman, 2013:201). Untuk itu, Islam tentunya juga mengatur konsep tentang hubungan manusia dalam lingkungan pekerjaan atau konsep kualitas kehidupan kerja atas kesejahteraan dan kebahagiaan hidup para karyawan dalam lingkungan pekerjaannya.

Islam juga hadir sebagai agama Rahmatan Lil 'Aalamiin (Rahmat bagi Sekalian Alam), yang tentunya memiliki konsep dalam menata kehidupan manusia agar senantiasa dalam kesejahteraan dan kebahagiaan, serta dalam kedamaian. Penerapan konsep tersebut dalam organisasi tidak lain adalah untuk menjamin adanya kualitas kehidupan kerja yang baik pagi para karyawan dalam organisasi. Dengan maksud lain konsep tersebut juga merupakan bagian yang tak terpisahkan dari konsep pandangan Islam tentang kualitas kehidupan kerja (Rahman, 2017:15-16).

Work family conflict adalah konflik yang terjadi pada individu akibat menanggung peran ganda baik dalam pekerjaan (work) maupun keluarga (family). Pembagian peran antara keluarga dan pekerjaan menjadi sebuah problematika yang dihadapi oleh karyawan wanita, nyatanya banyak wanita yang tidak cukup mampu untuk mengatasi permasalahan ini meskipun sudah memiliki strategi untuk menyiasatinya (Wulandari dan Andyani, 2016:815816).

Selain kedua faktor di atas, faktor yang dapat mempengaruhi turnover intention karyawan adalah sistem kompensasi karyawan. Kompensasi adalah sesuatu yang diterima 
oleh pekerja sebagai balas jasa atas pekerjaan mereka. Fungsi dari kompensasi yang diberikan diharapkan akan menarik pegawai, mempertahankan pegawai, memotivasi kinerja, dan mendorong peningkatan pengetahuan dan keterampilan karyawan (Paulus dan Winoto, 2015:82).

Salah satu industri yang menjadikan sumber daya manusia sebagai aset perusahaan adalahindustri Batik Tulis Bakaran. Batik Bakaran merupakan jenis batik tulis asli buatan orang Desa Bakaran. Batik Bakaran terpusat pada dua desa yaitu Bakaran Wetan dan Bakaran Kulon, Kecamatan Juwana. Jumlah pengrajin wanita pada Industri Pengrajin Batik Bakaran Wetan dan Kulon saat ini berjumlah 400 pengrajin. Wawancara awal dilakukan terhadap 40pengrajin yang bekerja pada Industri Batik Bakaran Juwana Pati.Wawancara dilakukan dengan memberikan pengrajin pertanyaan terkait dengan indikator-indikator tentang kualitas kehidupan kerja Islami, konflik pekerjaan-keluarga, sistem kompensasi, dan turnover intention. Setelah dilakukannya wawancara 36 dari 40pengrajin memang memiliki keinginan untuk keluar (turnover intention) dari industri tersebut yang di pengaruhi oleh kualitas kehidupan kerja Islami, konflik pekerjaan-keluarga, dan sistem kompensasi.

Berdasarkan hasil wawancara awal dengan 36 pengrajin industri batik tulis bakaran sebagaimana disebutkan sebelumnya, bahwa peningkatan keluar-masuk pengrajin wanita terjadi karena terdapat penurunan kepuasan kerja yang ditunjukkan dengan gejala-gejala yang terlihat yaitu menurunnya kegairahan pengrajin dalam melaksanakan pekerjaan, dikarenakan kurang perhatian terhadap sarana dan prasarana untuk menunjang kenyamanan melakukan pekerjaannya, seperti kondisi kursi pembatik yang perlu adanya perbaikan, dan lingkungan kerjanya yang kurang diperhatikan.

Penyebab lainnya kemangkiran yang dilakukan pengrajin adalah adanya tuntutan peran dalam pekerjaan yang dimana pengrajin merasa adanya tekanan atas beban pekerjaan dan terkait dengan pemberian upah atau kompensasi. Para wanita yang bekerja di Industri Batik Tulis Bakaran mempunyai peran yang sangat penting. Wanita selain sebagai ibu rumah tangga juga berprofesi sebagai tenaga kerja wanita. Setiap hari para wanita yang bekerja sebagai pembatik, menghabiskan waktunya untuk membuat batik di industri tempat mereka bekerja. Semua itu dilakukan karena untuk membantu perekonomian keluarga, yang kurang mencukupi kebutuhan. Tetapi disisi lain mereka juga memikirkan kondisi anak-anaknya di rumah yang juga butuh perhatian. Banyak dari mereka yang lebih memilih untuk pindah kerja di TPI Juwana yang dikira dari segi pekerjaannya tidak serumit membatik, lebih santai, dan terutama dari segi upahnya lebih memadai dan bisa mencukupi kebutuhan.

Di samping itu juga karena sistem kompensasi pengrajin yang kurang memadai dibandingkan dengan tenaga yang dikeluarkan, artinya penghasilan mereka dianggap kurang mampu menutup kebutuhan sehari-hari. Sistem pengupahan yang digunakan dalam industri batik tulis bakaran ini adalah sistem borongan. Rata-rata upah yang diberikan pemilik industri kepada para pekerja dihitung per jumlah produksi yang dapat diselesaikan oleh pekerja. Untuk setiap satu motif batik para pekerja hanya diberi upah Rp 15.000 - Rp 25.000 tergantung tingkat kerumitan pola batik yang dikerjakan tersebut. Berdasarkan wawancara dengan pengrajin batik bakaran mengatakan bahwa pekerjaan membatik bukan pekerjaan yang mudah. Butuh ketelitian, kesabaran, dan ketahanan fisik untuk menciptakan sehelai kain batik tulis. Mereka harus duduk selama 8-12 jam sehari, tanpa bersandar. Maka dari itu 
mereka menginginkan perubahan pemberian kompensasi yang sedikit diberi perhatian sesuai dengan tenaga yang dikeluarkan. Selain pemberian gaji yang dianggap belum bisa memenuhi kebutuhan, karyawan pembatik di Industri Batik Tulis Bakaran Juwana juga tidak mendapatkan insentif ataupun tunjangan-tunjangan dari tempat dia kerja, meskipun sudah lama menjadi seorang karyawan.

Tantangan ini yang menjadi pemicu semua industri UMKM untuk lebih profesional dalam mengelola sumber daya manusia secara maksimal, diantaranya harus memperhatikan kualitas kehidupan kerja secara Islami, konflik pekerjaan keluarga dan pemberian kompensasi karyawannya agar dapat meningkatkan profesionalitas kerja yang pada akhirnya berdampak pada produktifitas. Sebagai gerak sektor untuk menciptakan pertumbuhan dan lapangan pekerjaan, suatu UMKM dituntut untuk dapat mengelola sumber daya manusia yang dimiliki secara profesional sehingga mampu berkompetisi dengan UMKM lainnya yang semakin berkembang pesat.

Oleh karena itu, berdasarkan fenomena tersebut peneliti tertarik untuk meneliti lebih jauh mengenai “Analisis Pengaruh Islamic Quality of Work-Life, Work Family Conflict, dan Sistem Kompensasi terhadap Turnover Intention Pengrajin pada Industri Batik Tulis Bakaran Juwana Pati”.

\section{TINJAUAN LITERATUR}

\section{Teori Hierarki Kebutuhan oleh Abraham Maslow 1943}

Penelitian ini menggunakan teori kebutuhan Abraham H. Maslow. Teori ini mengatakan bahwa manusia sebagai makhluk yang tidak akan puas hanya dengan terpenuhi satu kebutuhan, tetapi ia akan puas jika semua kebutuhan terpenuhi. Hierarki kebutuhan manusia menurut Maslow adalah sebagai berikut:

a. Kebutuhan Fisiologis (PhysiologicalNeeds)

Kebutuhan fisiologis terdiri dari kebutuhan dasar, dan yang bersifat primer. Kebutuhan fisiologis biasanya dinamakan kebutuhan-kebutuhan biologikal dalam lingkungan kerja modern dan termasuk di dalamnya keinginan untuk mendapatkan pembayaran (upah/gaji), libur, rencanapensiun, periode-periode istirahat, lingkungan kerja yang menyenangkan, penerangan yang baik dan pada tempattempat kerja tertentu fasilitas AC. Kebutuhan fisiologis adalah kebutuhan yang paling kuat dan mendesak yang harus dipenuhi paling utama oleh manusia dalam menjalankan kehidupan kesehariannya (Iskandar, 2016:24).

\section{b. Kebutuhan Fisiologis (PhysiologicalNeeds)}

Setelah kebutuhan fisiologis terpenuhi, maka akan muncul kebutuhan akan keamanan, atau kebutuhan akan kepastian. Orang yang merasa tidak aman memiliki kebutuhan akan keteraturan dan stabilitas serta akan berusaha keras menghindari hal-hal yang bersifat asing dan tidak diharapkan. Kebutuhan akan keamanan merefleksi keinginan untuk mengamankan imbalan-imbalan yang telah dicapai dan untuk melindungi diri sendiri terhadap bahaya, cedera, ancaman, kecelakaan, kerugian atau kehilangan. Pada organisasiorganisasi kebutuhan-kebutuhan demikian terlihat pada keinginan pekerjaan akan kepastian pekerjaan, sistem-sistem senioritas, serikat pekerja, kondisi kerja aman, 
imbalan-imbalantambahan, asuransi, dan kemungkinan pensiun, tabungan, dan uang tunggu apabila terjadi hal-hal tertentu.

c. Kebutuhan Fisiologis (PhysiologicalNeeds)

Setelah kebutuhan fisiologikal dan keamanan selasai dipenuhi, maka perhatian sang individu beralih pada keinginan untuk mendapatkan kawan, cinta dan perasaan diterima. Sebagai makhluk sosial, manusia senang apabila mereka disenangi, dan berusaha memenuhi kebutuhan sosial pada waktu mereka bekerja, dengan jalan membantu kelompok-kelompok formal maupun informal, dan mereka bekerja sama dengan rekanrekan sekerja mereka, dan mereka turut terlibat dalam kegiatan pekerjaannya.

d. Kebutuhan Fisiologis (PhysiologicalNeeds)

Pada tingkatan keempat hieraki Maslow, terlihat kebutuhan individu akan penghargaan, atau juga dinamakan orang kebutuhan "ego". Kebutuhan ini berhubungan dengan hasrat yang untuk memiliki citra positif dan menerima perhatian, pengakuan, dan apresiasi dari orang lain. Dalam organisasi kebutuhan untuk dihargai menunjukan motivasi untuk diakui, tanggung jawab yang besar, status yang tinggi, dan pengakuan atas kontribusi pada organisasi.

e. Kebutuhan Fisiologis (PhysiologicalNeeds)

Kebutuhan ini adalah kebutuhan untuk mengalami pemenuhan diri, yang merupakan kategori kebutuhan tertinggi. Kebutuhan ini diantaranya adalah kebutuhan untuk mengembangkan potensi yang ada pada diri sendiri secara menyeluruh, meningkatkan kemampuan diri, dan menjadi orang yang lebih baik. Kebutuhan aktualisasi diri oleh organisasi dapat dipenuhi dengan memberikan kesempatan orang-orang untuk tumbuh, mengembangkan kreativitas, dan mendapatkan pelatihan untuk mendapatkan tugas yang menantang serta melakukan pencapaian (Iskandar, 2016:25-26).

Dalam penelitian ini, peneliti menggunakan teori kebutuhan karena peneliti akan melakukan studi empiris untuk mengetahui mengapa turnover intention terjadi sebagai akibat dari adanya kebutuhan seperti keinginan untuk mendapatkan pembayaran (upah/gaji), libur, rencana pensiun, periode-periode istirahat, lingkungan kerja yang menyenangkan, penerangan yang baik pada tempat kerja yang kurang diperhatikan dalam Industri Batik Tulis Bakaran Juwana Pati.

\section{Turnover Intention}

\section{Pengertian Turnover Intention}

Ida Ayu Diah Wulandari dan I Gusti Ayu Dewi Adnyani(2016:823), menyatakanturnover intention adalah keinginan untuk pindah kerja, belum sampai pada tahap realisasi untuk keluar dari suatu tempat kerja ke tempat lainnya. Keinginan pindah kerja (Turnover Intention) adalah kecenderungan atau niat karyawan untuk berhenti bekerja dari pekerjaannya secara sukarela atau pindah dari satu tempat ke tempat kerja yang lain menurut pilihannya sendiri. Menurut Andini (2006:12) dalam Wulandari dan Adnyani (2016) menyatakan bahwa keinginan untuk keluar muncul ketika karyawan tidak puas dengan organisasi tersebut dan mencari pekerjaan diluar.

\section{Dimensi Turnover Intention}


Menurut Adenguna (2013) dalam Wulandari dan Adnyani (2016:824), dimensi turnover intention ada dua yaitu:

1) Keinginan untuk mencari pekerjaan

Merupakan keinginan untuk mencari pekerjaan baru dikarenakan pekerjaan tersebut tidak sesuai dengan apa yang diharapkan oleh karyawan saat bekerja di perusahaanya saat ini.

2) Keinginan untuk meninggalkan atau berpindah

Merupakan keinginan untuk berpindah atau meninggalkan tempat kerja yang disebabkan dari pemikiran karyawan itu senidiri, dan biasanya pemikiran tersebut merupakan cerminan dari perasaan karyawan dari apa yang dirasakan selama bekerja.

\section{Dalil tentang turnover intention}

Pandangan Islam tentang intensi keluar (Turnover Intention) terdapat dalam QS. AlQashash ayat 77:

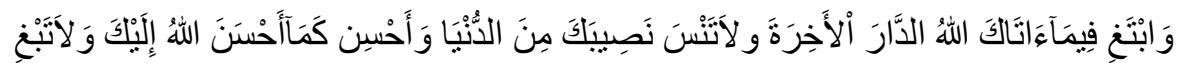

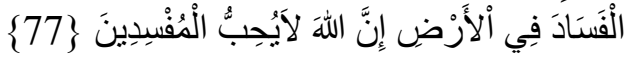

Artinya: "Dan carilah pada apa yang telah dianugerahkan Allah kepadamu (kebahagiaan) negeri akhirat, dan janganlah kamu melupakan bagiamu dari (kenikmatan) duniawi dan berbuat baiklah (kepada orang lain) sebagaimana Allah telah berbuat baik, kepadamu, dan janganlah kamu berbuat kerusakan di (muka) bumi. Sesungguhnya Allah tidak menyukai orang-orang yang berbuat kerusakan".

\section{Islamic Quality of Work Life}

\section{Pengertian Islamic Quality of Work Life}

Kualitas kehidupan kerja Islampada hakikatnya merupakan konsepyang membicarakan tentang kondisimenyeluruh atas kesejahteraan dankebahagiaan hidup para karyawan dalamlingkungan pekerjaannya (Zahoor, 2016:123).

\section{Dimensi Islamic Quality of Work Life}

Menurut Richard Walton dalam Zahoor (2016:124-125), dimensi Islamic quality of work life dapat dijelaskan sebagai berikut:

1) Adequate and fair compensation(Gaji yang memadai dan adil)

Penghargaan dari energi karyawan yang dimanifestasikan sebagai hasil produksi, atau suatu jasa yang dianggap sama untuk itu, yang berwujud uang, dengan suatu jaminan yang pasti dalam tiap-tiap minggu atau bulan. Berkaitan pula dengan kesesuaian antara gaji dengan standar sosial yang berkecukupan atau standar subyektif dari penerima.

2) Safe and healthy working condition (Lingkungan kerja yang aman dan sehat)

Suatu sistem pengendalian terhadap manusia, sarana, lingkungan kerja dan perangkat lunak. Aspek ini mencakup pula jam kerja yang masuk akal, kondisi kerja secara fisik yang meminimalisir resiko penyakit dan kecelakaan, dan juga batas usia yang dipaksakan saat kerja menjadi penghancur potensial bagi kesejahteraan orang tersebut yang berada pada umur di atas (maupun di bawah) usia tertentu. Lingkungan 
kerja yang aman dan sehat juga meliputi lingkungan kerja yang bebas dari kebisingan, bebas dari gangguan pandangan seperti pencahayaan dilingkungan kerja yang baik, dan bebas polusi.

3) Development of human capacities(Pengembangan kapasitas manusia)

Islam mendorong untuk melakukan pelatihan terhadap para karyawan dengan tujuan mengembangkan kompetensi dan kemampuan teknis karyawan dalam menunaikan tanggung jawab pekerjaanya. Sejauhmana pekerjaan yang digeluti karyawan memberikan kesempatan kepada karyawan untuk menggunakan dan mengembangkan segala kemampuan dan keterampilan yang dia miliki dan apakah pekerjaan tersebut memberikan tantangan bagi dirinya untuk terlibat seutuhnya. Kesempatan untuk tumbuh dan berkembang juga meliputi kesempatan untuk mengikuti pelatihan dan melanjutkan pendidikan sebagai upaya untuk mengembangkan kemampuan dalam melakukan pekerjaan.

4) Growth and security (Pertumbuhan dan Perkembangan)

Sejauhmana pekerjaan yang digeluti oleh karyawan dapat memberikan peluang bagi dirinya untuk maju dalam karier di masa yang akan datang.

5) Social integration in work organization (Integrasi sosial dalam lingkungan kerja)

Sejauhmana lingkungan pekerjaan dan rekan kerja dapat menerima kehadiran individu dan sejauhmana lingkungan kerja lepas dari prasangka yang destruktif. Apakah karyawan mencapai identitas personal dan kepercayaan diri dikarenakan keadaan di tempat kerja yang bebas dari prasangka, rasa kebersamaan antar grup, dan juga perasaan terbuka antar karyawan.

6) Constitutionalization in work organization (Konstitusi dalam lingkungan kerja)

Sejauhmana organisasi dapat memenuhi hak-hak yang semestinya dimiliki karyawan dan sejauhmana organisasi memberikan kebebasan terhadap keleluasaan pribadi, seperti budaya organisasi yang menghargai keleluasaan pribadi, mentoleransi perbedaan dan adanya kesempatan untuk mengungkapkan pendapat, dan juga adanya kesetaraan dalam pendistribusian reward dari organisasi.

7) Work and total life space (Keseimbangan antara kehidupan kerja dan pribadi)

Sejauhmana pekerjaan mempengaruhi peranan-peranan hidup pribadi karyawan, seperti hubungan dengan keluarga. Menitikberatkan pada adanya keseimbangan peran dari kerja pada kehidupan si karyawan sebenarnya. Konsep dari peran yang seimbang berkaitan pula dengan jam kerja, permintaan karier, diberikan waktu berlibur, termasuk juga adanya waktu senggang dan waktu untuk keluarga.

8) Social relevance of work life (Relevansi sosial kehidupan kerja)

Sejauhmana organisasi memiliki tanggung jawab sosial terhadap lingkungannya, sejauhmana organisasi dapat memberikan kebanggaan kepada karyawannya, dan lainlain.

\section{Dalil tentang kualitas kehidupan kerja Islam}

Sebagai seorang karyawan yang bekerja hendaknya seorang muslim mendapatkan haknya sebagai imbalan dari apa yang dia kerjakan. Kualitas kehidupan Kerja Islam 
mencerminkan bagaimana seorang atasan memberikan balasan yang baik bagi setiap karyawannya. Seperti Firman Allah dalam Al-Quran Surat At-Taubah: 105:

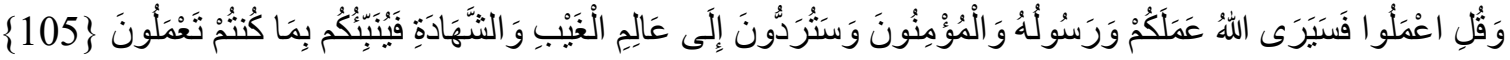

Artinya:Dan katakanlah, "bekerjalah kamu, maka Allah akan melihat pekerjaanmu, begitu juga Rasul-Nya dan orang-orang mukmin, dan kamu akan dikembalikan kepada (Allah) yang mengetahui yang ghaib dan yang nyata, lalu diberitakan-Nya kepada kamu apa yang telah kamu kerjakan."

Dijelaskan dalam ayat di atas, bahwasannya seorang karyawan yang bekerja hendaknya bekerja dengan motivasi yang tinggi dan kesungguhan sehingga mempunyai keterlibatan yang tinggi seperti halnya dalam kualitas kehidupan kerja.

\section{Work Famiy Conflict}

\section{Pengertian Work Famiy Conflict}

Greenhaus dan Beutell (1985)dalam Wulandari dan Andyani (2016:815), menyatakan bahwa konflik pekerjaan-keluarga (work family conflict)adalah konflik yang terjadi pada individu akibat menanggung peran ganda baik dalam pekerjaan (work) maupun keluarga (family). Kecenderungan ini terjadi karena jam kerja dan beban pekerjaan yang dimiliki oleh seorang karyawan terlalu padat, seluruh perhatian dan pikiran terlalu tercurahkan pada satu peran saja.Pada dasarnya bahwa work family conflict ini dapat terjadi pada pria maupun wanita, namun beberapa penelitian menunjukkan bahwa wanita memiliki intensitas yang lebih besar terjadinya work family conflict.

\section{Dimensi Work Famiy Conflict}

Menurut Abbot et al.(1998) dalam Wulandari dan Andyani (2016:823) ada indikator untuk mengukur work family conflict, yaitu:

1) Work Demand (Tekanan Pekerjaan)

Work demand adalah suatu tekanan yang timbul akibat adanya kelebihan dalam beban pekerjaannya dan juga akibat tekanan waktu (deadlines).

2) Family Demand (Tekanan Keluarga)

Family demandmerupakan suatu tekanan yang timbul karena adanya tekanan waktu dalam menyelesaikan tugas-tugas rumah (house-keeping) dan juga child care.

\section{Dalil tentang work family conflict}

Kedudukan perempuan dalam Islam dijelaskan dalam Surat At-Taubah: 71:

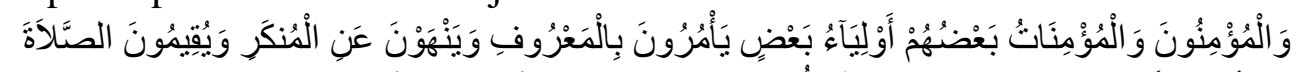

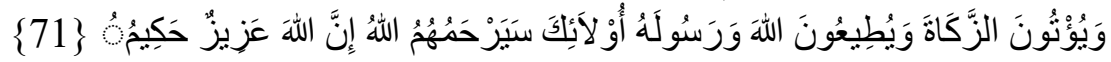

Artinya: "Dan orang-orang yang beriman, laki-laki dan perempuan, sebagian mereka adalah menjadi penolong bagi sebagian yang lain. Mereka menyuruh mengerjakan yang baik, mencegah yang munkar, mendirikan sholat, menunaikan zakat, dan mereka taat kepada Allah dan Rasul-Nya, mereka itulah yang akan diberi rahmat oleh Allah: sesungguhnya Allah maha Perkasa dan maha Bijaksana”. 
Ayat di atas dapat dipahami, bahwa laki-laki dan perempuan saling tolong-menolong, terutama dalam suatu urusan rumah tangga dan memiliki tugas dan kewajiban yang sama untuk menjalankan amar ma'ruf dan nahi munkar. Namun ada perintah Allah yang ditujukan kepada masing-masing individu, yakni mengerjakan sholat, puasa, zakat, dan lainnya.

Ada beberapa keadaan yang memperbolehkan bahkan mengharuskan wanita bekerja. M. Qutub dalam Quraish Shihab menjelaskan bahwa perempuan pada zaman Nabi Muhammad pun bekerja karena keadaan menuntut mereka untuk bekerja untuk kebutuhan masyarakat atau karena sangat membutuhkan manakala tidak ada yang menanggung baiaya hidupnya atau yang menanggung tidak bisa mencukupi kebutuhannya (Shihab, 1998:306).

\section{Sistem Kompensasi}

\section{Pengertian Kompensasi}

Fransiskus Billy Sandy (2019:3) menyatakan bahwa kompensasi merupakan pemberian yang diterima seorang karyawan dari perusahaan, baik finansial maupun non finansial, sebagai balas jasa kepada karyawan karena sudah melakukan pekerjaannya. Kepuasan atau ketidakpuasan karyawan akan pemberian kompensasi yang diterima menjadi salah satu faktor yang menentukan tinggi rendahnya niat ingin pindah kerja seorang karyawan untuk tetap bekerja di perusahaannya atau ingin pindah ke perusahaan lainnya. Imbalan atau kompensasi diharapkan akan meningkatkan rasa memiliki dan kecintaan terhadap perusahaannya di tempat mereka bekerja

\section{Dimensi Kompensasi}

Menurut Fransiskus Billy Sandy (2019:8), kompensasi dibagi ke dalam dua bentuk umum yaitu:

1) Kompensasi langsung

Merupakan pembayaran yang diterima oleh seseorang dalam bentuk gaji, dan insentif.

2) Kompensasi tidak langsung

Kompensasi yang berbentuk program kesejahteraan dan pelayanan. Kompensasi tidak langsung dapat dikelompokkan ke dalam dua jenis yaitu yang disediakan secara sukarela oleh pengusaha/majikan/pimpinan dan yang diwajibkan oleh hukum/peraturan. Contoh berupa fasilitas-fasilitas, seperti asuransi-asuransi, tunjangan, dan lain-lain.

\section{Dalil tentang kompensasi}

Dalam Islam kompensasi haruslah diberikan kepada karyawan sebagai imbalan yang telah dijanjikan oleh para pemberi kerja, pemberi kerja akan mendapatkan hasil dari pekerjaan yang telah selesai dikerjakan sedangkan pekerja akan mendapatkan upah atau kompensasi dari tenaga yang dikeluarkannya. Hal ini sesuai dengan firman Allah dalam QS. Al-Kahfi ayat 30:

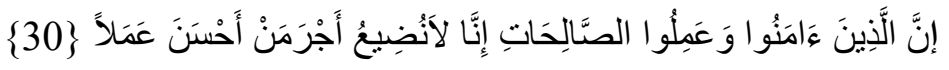

Artinya: "Sesungguhnya mereka yang beriman dan beramal saleh tentulah kami tidak akan menyia-nyiakan pahala orang-orang yang mengerjakan amalan(nya) dengan baik". 
Ayat di atas menegaskan bahwa balasan terhadap pekerjaan yang telah dilakukan manusia, pasti Allah balas dengan adil. Allah tidak akan berlaku zalim dengan cara menyia-nyiakan amal hamba-Nya. Konsep keadilan dalam upah inilah yang sangat mendominasi dalam setiap praktek yang pernah terjadi di negeri Islam.

\section{Hipotesis}

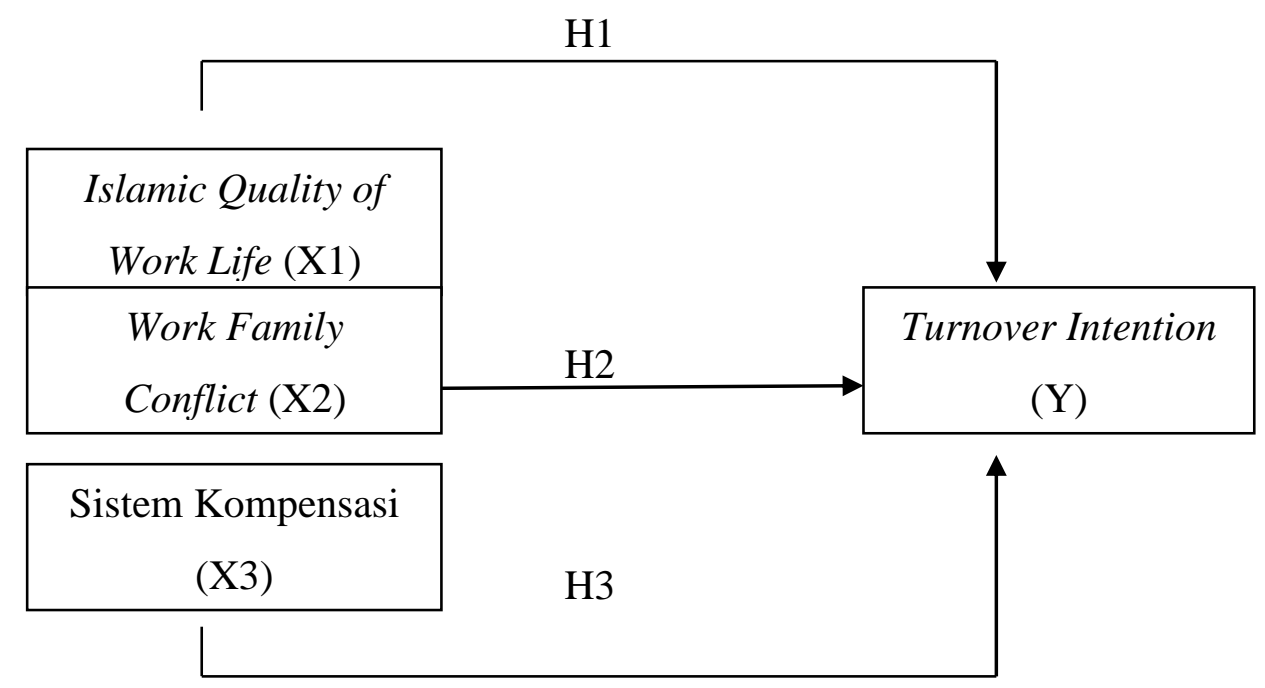

Gambar 1. Model Hipotesis

Keterangan:

H1: Variabel Islamic Quality of Work Lifeberpengaruh terhadap turnover intention

H2: Variabel Work Family Conflictberpengaruh terhadap turnover intention

X3: Variabel Work Family Conflictberpengaruh terhadap turnover intention

\section{METODE PENELITIAN}

\section{Metode, Variabel dan Lokasi Penelitian}

Penelitian ini menggunakan metode kuantitatif dengan analisis regresi berganda. Objek dalam penelitian ini terdiri dari empat variabel, yaitu variabel eksogen dan variabel endogen. Variabel Eksogen terdiri dari Variabel Islamic Quality of Work Life (X1), Variabel Work Family Conflict (X2), dan Variabel Sistem Kompensasi (X3), sedangkan variabel endogen yaitu Turnover Intention (Y). Lokasi Penelitian dilakukan di Industri Batik Tulis Bakaran Juwana Pati.

\section{Populasi dan Sampel}

Populasi dalam penelitian ini adalah seluruh pengrajin Industri Batik Tulis Bakaran Juwana Pati yang berjumlah 400 pengrajin. Dalam penelitian ini, tidak semua pengrajin dijadikaan sampel. Teknik sampling yang digunakan adalah metode simple random sampling. Teknik analisa penentuan sampel dihitung dengan menggunakan rumus slovin dengan tingkat kesalahan 5\%. Sehingga jumlah sampel dalam penelitian ini adalah 200 pengrajin. 


\section{Definisi Operasional}

Tabel 1. Definisi Operasional

\begin{tabular}{|c|c|c|c|c|c|}
\hline Variabel & $\begin{array}{c}\text { Definisi } \\
\text { Operasional }\end{array}$ & Dimensi & Indikator & Skala & Sumber \\
\hline $\begin{array}{l}\text { Islamic } \\
\text { Quality of } \\
\text { Work } \\
\text { (X1) }\end{array}$ & $\begin{array}{l}\text { konsep yang } \\
\text { membicarakan } \\
\text { tentang kondisi } \\
\text { menyeluruh } \\
\text { atas } \\
\text { kesejahteraan } \\
\text { dan } \\
\text { kebahagiaan } \\
\text { hidup para } \\
\text { karyawan } \\
\text { dalam } \\
\text { lingkungan } \\
\text { pekerjaannya. }\end{array}$ & $\begin{array}{l}\text { 1. Adequate and } \\
\text { Fair } \\
\text { Compensation } \\
\text { 2. Safe and } \\
\text { Healthy } \\
\text { Working } \\
\text { 3. Development } \\
\text { of Human } \\
\text { Capacities } \\
\text { 4. Growth and } \\
\text { Security } \\
\\
\text { 5. Social } \\
\text { Integration in } \\
\text { Work } \\
\text { Organization } \\
\text { 6. Constitutional } \\
\text { ization in } \\
\text { Work } \\
\text { Organization } \\
\text { 7. Work and } \\
\text { Total Life } \\
\text { Space } \\
\text { 8. Social } \\
\text { Relevance in } \\
\text { Work Life }\end{array}$ & $\begin{array}{l}\text { a. Fair compensation } \\
\text { b. Participation in } \\
\text { results } \\
\text { a. Weekly Journey } \\
\text { b. Salubrity } \\
\text { a. Autonomy } \\
\text { b. Importance of the } \\
\text { task } \\
\text { a. Professional } \\
\text { growth } \\
\text { b. Trainings } \\
\text { a. Discrimination } \\
\text { b. Interpersonal } \\
\text { relationship } \\
\text { a. Worker's right } \\
\text { b. Discussion and } \\
\text { norms } \\
\text { a. Influence on the } \\
\text { family routine } \\
\text { b. Leisure possibility } \\
\text { a. Proud of work } \\
\text { b. Politics of human } \\
\text { resource }\end{array}$ & Likert & $\begin{array}{l}\text { Zeenat } \\
\text { Zahoor } \\
(2016)\end{array}$ \\
\hline
\end{tabular}




\begin{tabular}{|c|c|c|c|c|c|}
\hline Variabel & $\begin{array}{c}\text { Definisi } \\
\text { Operasional }\end{array}$ & Dimensi & Indikator & Skala & Sumber \\
\hline $\begin{array}{l}\text { Work Family } \\
\text { Conflict (X2) }\end{array}$ & $\begin{array}{l}\text { Konflik yang } \\
\text { terjadi pada } \\
\text { individu akibat } \\
\text { menanggung } \\
\text { peran ganda } \\
\text { baik dalam } \\
\text { pekerjaan } \\
\text { (work) maupun } \\
\text { keluarga } \\
\text { (family). }\end{array}$ & $\begin{array}{l}\text { 2. Family } \\
\text { Demand } \\
\text { (Tekanan } \\
\text { Keluarga) }\end{array}$ & $\begin{array}{l}\text { a. Bertentangan } \\
\text { dengan kehidupan } \\
\text { keluarga } \\
\text { b. Kesulitan } \\
\text { memenuhi } \\
\text { tanggungjawab } \\
\text { keluarga } \\
\text { c. Sesuatu di rumah } \\
\text { tidak dapat } \\
\text { terselesaikan } \\
\text { d. Menimbulkan } \\
\text { ketegangan untuk } \\
\text { memenuhi tugas } \\
\text { keluarga } \\
\text { e. Mengakibatkan } \\
\text { perubahan rencana } \\
\text { untuk kegiatan } \\
\text { keluarga } \\
\text { a. Adanya tuntutan } \\
\text { suami } \\
\text { b. Adanya tuntutan } \\
\text { waktu di rumah } \\
\text { c. Permintaan } \\
\text { keluarga berkaitan } \\
\text { dengan anak. } \\
\text { d. Kehidupan rumah } \\
\text { tangga } \\
\text { mengganggu } \\
\text { kewajiban dalam } \\
\text { pekerjaan } \\
\text { e. Ketegangan dari } \\
\text { keluarga } \\
\text { mengganggu } \\
\text { aktivitas pekerjaan }\end{array}$ & Likert & $\begin{array}{l}\text { Ida Ayu } \\
\text { Diah } \\
\text { Wulandari } \\
\text { dan I Gusti } \\
\text { Ayudewi } \\
\text { Andyani } \\
(2016)\end{array}$ \\
\hline
\end{tabular}




\begin{tabular}{|c|c|c|c|c|c|}
\hline Variabel & $\begin{array}{c}\text { Definisi } \\
\text { Operasional }\end{array}$ & Dimensi & Indikator & Skala & Sumber \\
\hline $\begin{array}{l}\text { Sistem } \\
\text { Kompensasi } \\
(\mathrm{X} 3)\end{array}$ & $\begin{array}{l}\text { Sesuatu yang } \\
\text { diterima oleh } \\
\text { karyawan } \\
\text { sebagai balasan } \\
\text { atas karya yang } \\
\text { diberikannya } \\
\text { kepada } \\
\text { organisasi. }\end{array}$ & $\begin{array}{l}\text { 2. Kompensasi } \\
\text { Tidak } \\
\text { Langsung }\end{array}$ & $\begin{array}{l}\text { a. Gaji dapat } \\
\text { memenuhi } \\
\text { kebutuhan } \\
\text { b. Gaji diberikan } \\
\text { tepat waktu } \\
\text { c. Gaji sesuai beban } \\
\text { kerja } \\
\text { d. Insentif dapat } \\
\text { memenuhi } \\
\text { kebutuhan } \\
\text { e. Insentif sesuai } \\
\text { dengan beban kerja } \\
\text { f. Insentif diberikan } \\
\text { tepat waktu } \\
\text { a. Tunjangan yang } \\
\text { sesuai harapan } \\
\text { b. Adanya jaminan } \\
\text { sosial fasilitas } \\
\text { c. Adanya dari } \\
\text { pendukung an } \\
\text { perusahaan } \\
\text { d. Memberikan } \\
\text { peluang untuk } \\
\text { berkarir dan } \\
\text { berkembang }\end{array}$ & Likert & $\begin{array}{l}\text { Fransiskus } \\
\text { Billy } \\
\text { Sandy } \\
\text { (2019) }\end{array}$ \\
\hline
\end{tabular}




\begin{tabular}{|c|c|c|c|c|c|}
\hline Variabel & $\begin{array}{c}\text { Definisi } \\
\text { Operasional }\end{array}$ & Dimensi & Indikator & Skala & Sumber \\
\hline $\begin{array}{l}\text { Turnover } \\
\text { Intention (Y) }\end{array}$ & $\begin{array}{l}\text { Keinginan } \\
\text { untuk } \\
\text { berpindah, } \\
\text { belum sampai } \\
\text { pada tahap } \\
\text { realisasi untuk } \\
\text { keluar dari } \\
\text { suatu tempat } \\
\text { kerja ke tempat } \\
\text { lainnya. }\end{array}$ & $\begin{array}{l}\text { 2. Keinginan } \\
\text { untuk } \\
\text { Meninggalkan }\end{array}$ & $\begin{array}{l}\text { a. Akan keluar dari } \\
\text { perusahaan apabila } \\
\text { ada tawaran dan } \\
\text { kesempatan yang } \\
\text { lebih baik } \\
\text { b. Aktif mencari } \\
\text { lowongan } \\
\text { pekerjaan baru } \\
\text { c. Akan tidak masuk } \\
\text { kerja jika ada } \\
\text { jadwal wawancara } \\
\text { dengan perusahaan } \\
\text { lain } \\
\text { d. Sering tidak masuk } \\
\text { kerja karena } \\
\text { keperluan di luar } \\
\text { pekerjaan lebih } \\
\text { penting } \\
\text { e. Sering menunda } \\
\text { tugas karena } \\
\text { adanya } \\
\text { kepentingan lain } \\
\text { a. Sering terlambat } \\
\text { masuk kerja } \\
\text { b. Melemparkan } \\
\text { kesalahan jika } \\
\text { tidak mampu } \\
\text { menyelesaikannya } \\
\text { c. Tidak yakin akan } \\
\text { karir akan } \\
\text { meningkat jika } \\
\text { masih bekerja di } \\
\text { sini }\end{array}$ & Likert & $\begin{array}{l}\text { Ida Ayu } \\
\text { Diah } \\
\text { Wulandari } \\
\text { dan I Gusti } \\
\text { Ayu Dewi } \\
\text { Adnyani } \\
(2016)\end{array}$ \\
\hline
\end{tabular}



d. Peningkatan
terhadap
pelanggaran
kebijakan
perusahaan
e. Peningkatan protes
terhadap atasan

\section{Metode Pengumpulan Data}

Dalam penelitian ini teknik pengumpulan data yang digunakan yaitu penelitian lapangan dengan melakukan penyebaran kuesioner. Jenis data yang digunakan adalah data primen yang berupa hasil dari kuesioner. Teknik analisis data dalam penelitian ini adalah analisis regresi linier berganda dengan menggunakan Program IBM SPSS Statistik Versi 21.0 .

\section{HASIL PENELITIAN DAN PEMBAHASAN \\ Hasil Uji Validitas dan Reliabilitas Non Responden}

Tabel 2. Hasil Uji Validitas Instrumen Non Responden

\begin{tabular}{ccccc}
\hline Variabel & Item & $\begin{array}{c}\text { Corrected } \\
\text { Item- Total } \\
\text { Correlation }\end{array}$ & r tabel & Keterangan \\
\hline Islamic & P1 & 0,424 & 0,3610 & Valid \\
Quality of & P2 & 0,733 & 0,3610 & Valid \\
Work Life & P3 & 0,396 & 0,3610 & Valid \\
$(\mathrm{X} 1)$ & P4 & 0,809 & 0,3610 & Valid \\
& P5 & 0,869 & 0,3610 & Valid \\
& P6 & 0,567 & 0,3610 & Valid \\
& P7 & 0,869 & 0,3610 & Valid \\
& P8 & 0,718 & 0,3610 & Valid \\
& P9 & 0,567 & 0,3610 & Valid \\
& P10 & 0,809 & 0,3610 & Valid \\
& P11 & 0,869 & 0,3610 & Valid \\
& P12 & 0,869 & 0,3610 & Valid \\
& P13 & 0,869 & 0,3610 & Valid \\
& P14 & 0,809 & 0,3610 & Valid \\
& P15 & 0,685 & 0,3610 & Valid \\
& P16 & 0,733 & 0,3610 & Valid \\
\hline Work Family & P1 & 0,942 & 0,3610 & Valid \\
Conflict(X2) & P2 & 0,942 & 0,3610 & Valid \\
& P3 & 0,934 & 0,3610 & Valid \\
& P4 & 0,926 & 0,3610 & Valid \\
& P5 & 0,922 & 0,3610 & Valid \\
& P6 & 0,936 & 0,3610 & Valid \\
\hline
\end{tabular}




\begin{tabular}{cccc}
\hline P7 & 0,904 & 0,3610 & Valid \\
P8 & 0,783 & 0,3610 & Valid \\
P9 & 0,783 & 0,3610 & Valid \\
P10 & 0,685 & 0,3610 & Valid
\end{tabular}

\begin{tabular}{ccccc}
\hline Variabel & Item & $\begin{array}{c}\text { Corrected } \\
\text { Item- Total } \\
\text { Correlation }\end{array}$ & r tabel & Keterangan \\
\hline Sistem & P1 & 0,734 & 0,3610 & Valid \\
Kompensasi & P2 & 0,470 & 0,3610 & Valid \\
(X3) & P3 & 0,634 & 0,3610 & Valid \\
& P4 & 0,806 & 0,3610 & Valid \\
& P5 & 0,728 & 0,3610 & Valid \\
& P6 & 0,634 & 0,3610 & Valid \\
& P7 & 0,728 & 0,3610 & Valid \\
& P8 & 0,806 & 0,3610 & Valid \\
& P9 & 0,736 & 0,3610 & Valid \\
& P10 & 0,734 & 0,3610 & Valid \\
& & & & \\
\hline Turnover & P1 & 0,644 & 0,3610 & Valid \\
& P2 & 0,483 & 0,3610 & Valid \\
& P3 & 0,687 & 0,3610 & Valid \\
& P4 & 0,750 & 0,3610 & Valid \\
& P5 & 0,762 & 0,3610 & Valid \\
& P6 & 0,687 & 0,3610 & Valid \\
& P7 & 0,762 & 0,3610 & Valid \\
& P8 & 0,750 & 0,3610 & Valid \\
& P9 & 0,746 & 0,3610 & Valid \\
& P10 & 0,767 & 0,3610 & Valid
\end{tabular}

Sumber: Data diolah, 2019

Tabel 3. Hasil Uji Reliabilitas Instrumen Non Responden

\begin{tabular}{cccc}
\hline Variabel & $\begin{array}{c}\text { Reliability } \\
\text { Coefficience }\end{array}$ & $\begin{array}{c}\text { Cronbach's } \\
\text { Alpha }(>\mathbf{0 , 6 0})\end{array}$ & Keterangan \\
\hline $\begin{array}{c}\text { Islamic Quality of } \\
\text { Work Life }(\mathrm{X} 1)\end{array}$ & 16 item & 0,951 & Reliabel \\
\hline $\begin{array}{c}\text { Work Family } \\
\text { Conflict }(\mathrm{X} 2)\end{array}$ & 10 item & 0,974 & Reliabel \\
\hline $\begin{array}{c}\text { Sisem Kompensasi } \\
(\mathrm{X} 3)\end{array}$ & 10 item & 0,921 & Reliabel \\
\hline $\begin{array}{c}\text { Turnover Intention } \\
(\mathrm{Y})\end{array}$ & 10 item & 0,922 & Reliabel \\
\hline
\end{tabular}


Uji validitas dilakukan dengan membandingkan antara nilai $\mathrm{r}$ hitung dengan nilai rtabel dengan tingkat signifikan 5\%. Nilai rhitung didapatkan dengan melihat skor item-total correlations tiap item pernyataan setiap variabelnya. Sedangkan untuk mendapatkan $r$ tabel dilakukan dengan menentukan degree of freedom (df) dari jumlah sampel (n) dimana $\mathrm{n}=30$, $\mathrm{df}=\mathrm{n}-2$, maka $\mathrm{df}=28$ sehingga didapat $\mathrm{df}=28$ dengan tingkat signifikansi $5 \%$ adalah 0,3061 dengan sumber acuan tabel $r$ tabel. Jika $r$ hitung $>r$ tabel dan nilai positif maka butir atau pertanyaan atau indikator tersebut dinyatakan valid (Ghozali, 2006:49). Hasil pengujian semua item pernyataan dari masing-masing variabel yaitu Islamic quality of work life(X1), work family conflict (X2), sistem kompensasi (X3) dan Turnover intention (Y) sudah memenuhi uji validitas karena semua $r$ hitung $>\mathrm{r}$ tabel. Sedangkan berdasarkan hasil uji reliabilitas instrument, dapat disimpulkan bahwa instrument yang digunakan untuk mengukur variabel Islamic quality of work life(X1), work family conflict(X2), sistem kompensasi(X3) dan turnover intention (Y) adalah reliabel, karena nilai Alpha Cronbach semua variabel > 0,70 (Nunnally, 1994 dalam Ghozali, 2011). Dimana nilai Alpha Cronbach masing-masing variabel sudah memenuhi uji reliabitas yakni0,951,0,974, 0,921 dan 0,922.

\section{Hasil Uji Asumsi Klasik}

Apabila nilai VIF kurang dari 10 dan Tolerance lebih dari 0,10 maka dinyatakan tidak terjadi multikolonieritas (Ghozali, 2011: 106). Berdasarkan hasil uji multikolonieritas Islamic Quality of Work Life (X1) nilai VIF 1,600 dan Tolerance 0,625, Work Family Conflict (X2) nilai VIF 1,013 dan Tolerance 0,987, dan Sistem Kompensasi (X3) nilai VIF 1,611 dan Tolerance 0,621, sehingga dapat disimpulkan bahwa ketiga variabel tersebut tidak terdapat masalah multikolonieritas.

Uji asumsi klasik selanjutnya adalah uji Heterokedastisitas dimana berdasarkanhasil uji Heteroskedastisitas terlihat pada gambar Scatterplot tidak terdapat titik-titik yangmembentuk pola-pola tertentu dan titik-titik tersebut terlihat menyebar. Sedangkan ujiNormalitas berdasarkan analisis grafik lewat SPSS dengan melihat dari probability plot $(P$ Plot), terlihat bahwa data menyebar disekitar garis diagonal dan mendekati arah garisdiagonal maka data dapat dikatakan berdistribusi normal atau dengan kata lain model regresitelah memenuhi asumsi normalitas.

\section{Gambar 2.}

\section{Hasil Uji Heterokedastisitas dan Normalitas} Normal P-P Plot of Regression Standardized
Residual

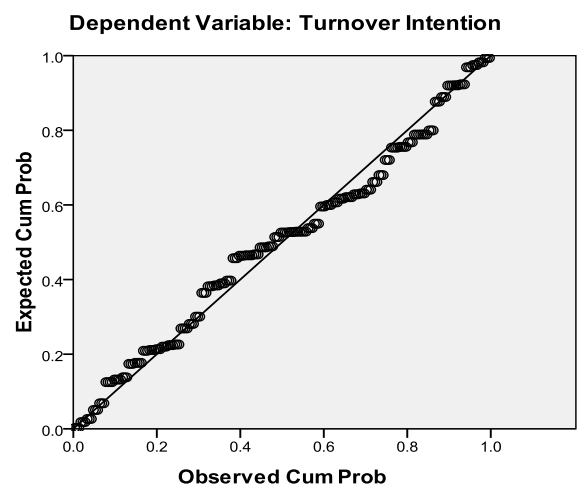




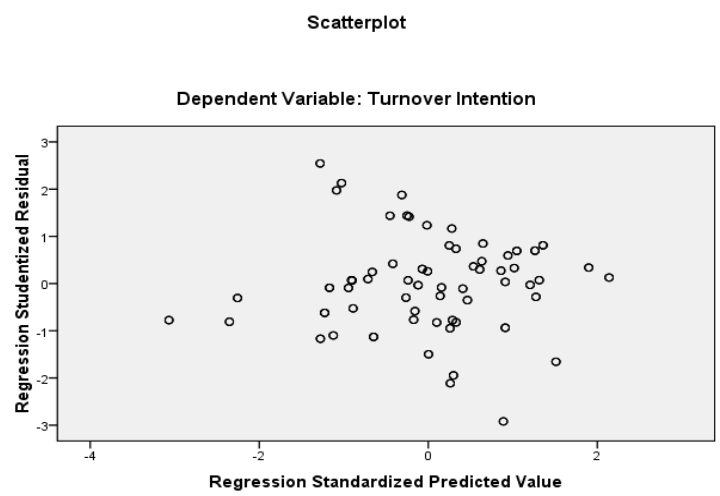

Sumber: Data diolah, 2019

\section{Hasil Analisis Data}

\section{Analisis Regresi Berganda}

Analisis ini dilakukan untuk menguji hipotesis dari penelitian yang telah dirumuskan sebelumnya, yaitu untuk mengetahui apakah ada pengaruh antara variabel Islamic quality of work life, work family conflictdan sistem kompensasiterhadap turnover intention pengrajin. Maka dapat diketahui hasilnya pada tabel di bawah ini:

Tabel 4. Hasil Analisis Regresi Berganda

\section{Coefficients $^{\mathrm{a}}$}

\begin{tabular}{|c|c|c|c|c|c|c|}
\hline \multirow[b]{2}{*}{ Mod } & & \multicolumn{2}{|c|}{$\begin{array}{l}\text { Unstandardized } \\
\text { Coefficients }\end{array}$} & $\begin{array}{c}\text { Standardized } \\
\text { Coefficients } \\
\end{array}$ & \multirow[b]{2}{*}{$\mathbf{t}$} & \multirow[b]{2}{*}{ Sig. } \\
\hline & & B & $\begin{array}{l}\text { Std. } \\
\text { Error }\end{array}$ & Beta & & \\
\hline \multirow[t]{4}{*}{1} & (Constant) & 17.713 & 2.741 & & 6.462 & .000 \\
\hline & $\begin{array}{l}\text { Islamiq Quality of Work } \\
\text { Life }\end{array}$ & .138 & .038 & .244 & 3.591 & .000 \\
\hline & Work Family Conflict & -.155 & .047 & -.179 & -3.311 & .001 \\
\hline & Sistem Kompensasi & .482 & .069 & .474 & 6.938 & .000 \\
\hline
\end{tabular}

a. Dependent Variable: Turnover Intention

Sumber: Data diolah, 2019

Dari hasil tabel di atas, maka bentuk persamaan regresi dalam peneltian ini adalah sebagai berikut:

$$
\begin{aligned}
& Y=a+b_{1} X_{1}+b_{2} X_{2}+b_{3} X_{3}+e \\
& Y=17,713+-0,138 X_{1}+0,155 X_{2}+0,482 X_{3}+e
\end{aligned}
$$

Di mana: 


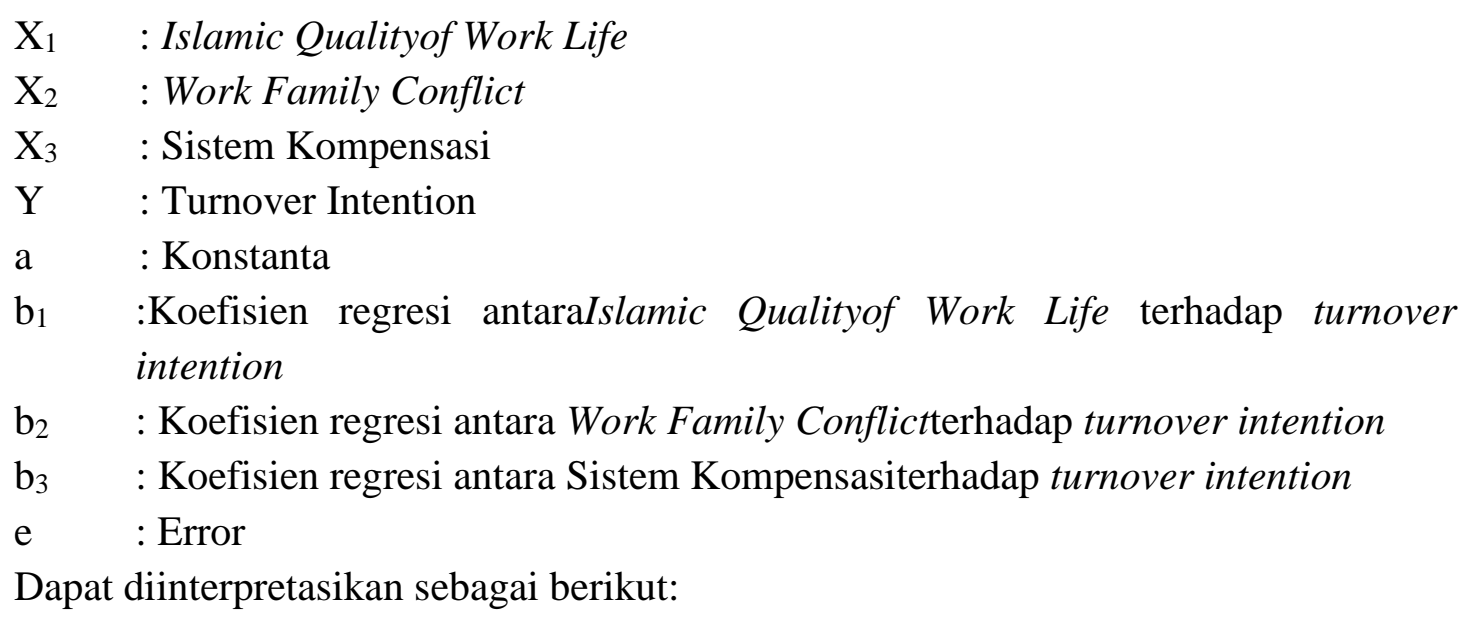

a. Nilai $\beta_{1}=0,138$, menunjukan bahwa islamic quality of work life memberi pengaruh positif terhadap turnover intention pengrajin padaIndustri Batik Tulis Bakaran Juwana Pati sebesar 0,138, artinya apabila islamic quality of work life tinggi, maka akan mengurangi terjadinya turnover intention.

b. Nilai $\beta_{1}=-0,138$, menunjukan bahwa work family conflict memberi pengaruh negatif terhadap turnover intention pengrajin pada Industri Batik Tulis Bakaran Juwana Pati sebesar -0,138, artinya apabila work family conflictrendah, maka akan mengurangi terjadinya turnover intention.

c. Nilai $\beta_{1}=0,482$, menunjukan bahwa sistem kompensasi memberi pengaruh positif terhadap turnover intention pengrajin pada Industri Batik Tulis Bakaran Juwana Pati sebesar 0,482, artinya apabila sistem kompensasi tinggi, maka akan mengurangi terjadinya turnover intention.

\section{Koefisien Determinasi/Rsquare}

Tabel 5. Hasil Uji Koefesien Determinasi

\begin{tabular}{lcccc}
\hline \multicolumn{4}{c}{ Model Summary $^{\mathbf{b}}$} \\
\hline Model & $\mathrm{R}$ & R Square & $\begin{array}{c}\text { Adjusted R } \\
\text { Square }\end{array}$ & $\begin{array}{l}\text { Std. Error of } \\
\text { the Estimate }\end{array}$ \\
\hline 1 & $.658^{\text {a }}$ & .432 & .424 & 5.19726 \\
\hline a. Predictors: (Constant), Sistem Kompensasi, Work Family Conflict, \\
Islamiq Quality of Work Life \\
b. Dependent Variable: Turnover Intention
\end{tabular}

Sumber: Data diolah, 2019

Berdasarkan hasil analisa regresi linear berganda Nilai Adjusted R2 untuk model penelitian ini yaitu 0,424 nilai ini berarti $42,4 \%$ variasi dari turnover intention dapat dijelaskan oleh variasi dari variabel stres kerja, kompensasi dan kepuasan kerja sedangkansisanya sebesar0,576atau 57,6\% dijelaskan oleh faktor-faktor lain yang tidak dimasukkan dalam penelitian ini. Hal ini menunjukkan bahwa faktor-faktor variabel yang 
digunakan dalam penelitian ini sudah mewakili variabel-variabel lain yang dapat mempengaruhi turnoverintention.

\section{Uji F}

Tabel 6. Hasil Uji F

\begin{tabular}{llrrrrr}
\hline \multicolumn{7}{c}{ ANOVA $^{\mathbf{b}}$} \\
\hline Model & & Sum of Squares & Df & Mean Square & F & \multicolumn{1}{c}{ Sig. } \\
\hline 1 & Regression & 4032.067 & 3 & 1344.022 & 49.757 & $.000^{\text {a }}$ \\
& Residual & 5294.253 & 196 & 27.011 & & \\
& Total & 9326.320 & 199 & & & \\
\hline
\end{tabular}

a. Predictors: (Constant), Sistem Kompensasi, Work Family Conflict, Islamiq Quality of Work Life

b. Dependent Variable: Turnover Intention

Sumber: Data diolah, 2019

Berdasarkan tabel di atas, maka dalam penelitian ini memiliki nilai $\mathrm{F}$ hitung sebesar 18,685. Dengan demikian nilai F hitung > Ftabel $(49,757>2,65)$. Maka dapat disimpulkan bahwa variabelislamic quality of work life, work family conflict, dan sistem kompensai secara simultan atau bersama-sama berpengaruh terhadap turnover intention pengrajin pada Industri Batik Tulis Bakaran Juwana Pati.

\section{Hasil Uji Hipotesis}

Tabel 7. Hasil Uji Hipotesis

\begin{tabular}{|c|c|c|c|c|c|c|}
\hline \multicolumn{7}{|c|}{ Coefficients $^{\mathrm{a}}$} \\
\hline & \multirow[b]{2}{*}{ Model } & \multicolumn{2}{|c|}{$\begin{array}{l}\text { Unstandardized } \\
\text { Coefficients }\end{array}$} & \multirow{2}{*}{$\begin{array}{c}\text { Standardized } \\
\text { Coefficients } \\
\text { Beta }\end{array}$} & \multirow[b]{2}{*}{$\mathrm{T}$} & \multirow[b]{2}{*}{ Sig. } \\
\hline & & $\mathrm{B}$ & $\begin{array}{l}\text { Std. } \\
\text { Error }\end{array}$ & & & \\
\hline \multirow[t]{4}{*}{1} & (Constant) & 17.713 & 2.741 & & 6.462 & .000 \\
\hline & $\begin{array}{l}\text { Islamiq Quality of } \\
\text { Work Life }\end{array}$ & .138 & .038 & .244 & 3.591 & .000 \\
\hline & Work Family Conflict & -.155 & .047 & -.179 & -3.311 & .001 \\
\hline & Sistem Kompensasi & .482 & .069 & .474 & 6.938 & .000 \\
\hline
\end{tabular}

a. Dependent Variable: Turnover Intention

Sumber: Data diolah, 2019

\section{Pengaruh Islamic Quality of Work Life terhadap Turnover Intention $\left(\mathrm{H}_{1}\right)$}

Berdasarkan hasil uji hipotesis 1 (H1), didapat bahwa pada tingkat signifikansi dibawah 0,05 Perbandingan nilai antara t hitung sebesar 3,591 lebih besar dengan nilai t tabel sebesar 2,015 sehingga menunjukkan bahwa pengaruh variabel Islamic Quality of 
Work Life (X1) terhadap Turnover Intention (Y) secara parsial adalah berpengaruhdan signifikan serta t hitung sebesar 5,593 menunjukkan bahwa variabel Islamic Quality of Work Life pada pengrajin Industri Batik Tulis Bakaran Juwana Pati berpengaruh positif terhadap Turnover Intention. Sehingga hasil pengujian hipotesis 1 (H1) terbukti.

\section{Pengaruh Work Family Conflict terhadap Turnover Intention $\left(\mathrm{H}_{2}\right)$}

Berdasarkan hasil uji hipotesis 2 (H2), didapat bahwa pada tingkat signifikansi dibawah 0,05 Perbandingan nilai antara thitung sebesar -3,311 lebih besar dengan nilai t tabel sebesar 2,015 sehingga menunjukkan bahwa pengaruh variabel Work Family Conflict (X2) terhadap Turnover Intention (Y) secara parsial adalah berpengaruh dan signifikan serta t hitung sebesar -3,311 menunjukkan bahwa variabel Work Family Conflictpada pengrajin Industri Batik Tulis Bakaran Juwana Pati berpengaruh negatif terhadap Turnover Intention. Sehingga hasil pengujian hipotesis 2 (H2) terbukti.

\section{Pengaruh Sistem Kompensasiterhadap Turnover Intention $\left(\mathbf{H}_{3}\right)$}

Berdasarkan hasil uji hipotesis 3 (H3), didapat bahwa pada tingkat signifikansi dibawah 0,05 Perbandingan nilai antara t hitung sebesar 6,938 lebih besar dengan nilai $t$ tabel sebesar 2,015 sehingga menunjukkan bahwa pengaruh variabel Sistem Kompensasi (X3) terhadap Turnover Intention (Y) secara parsial adalah berpengaruh dan signifikan serta t hitung sebesar 6,938 menunjukkan bahwa variabel Sistem Kompensasi pada pengrajin Industri Batik Tulis Bakaran Juwana Pati berpengaruh positif terhadap Turnover Intention. Sehingga hasil pengujian hipotesis 3 (H3) terbukti.

\section{IMPLIKASI HASIL PENELITIAN}

Berdasarkan perhitungan menggunakan aplikasi SPSS juga terlihat bahwa faktor sistem kompensasi memiliki pengaruh yang lebih besar dan dominan dibanding faktor Islamic quality of work life dan work family conflict terhadap turnover intention karyawan yakni sebesar 6,938.

Terkait dengan hasil jawaban responden terhadap pernyataan dari indikator Islamic quality of work life, work family conflict dan sistem kompensasi serta hasil pengujian hipotesisnya, maka terlihat gambaran bahwa ternyata faktor sistem kompensasi paling besar pengaruhnya terhadap turnoverintention pengrajin Industri Batik Tulis Bakaran Juwana Pati, setelah itu baru faktor Islamic quality of work life dan work family conflict yang mampu mempengaruhi turnover intention. Artinya pihak manajemen harus memperhatikan indikatorindikator terkait pemberiankompensasiyang sesuai dan adil dengan tenaga kerja yang dikeluarkan oleh pengrajin batik. Selain itu, industriharus tetap juga memperhatikan akan kualitas kehidupan kerja secara Islam terhadap karyawan dan memahami akan akibat work family conflict karyawan dalam bekerja.

\section{Keterbatasan Hasil Penelitian}

Adapun keterbatasan dalam penelitian ini adalah kuesioner hanya disebarkan kepada pengrajin Industri Batik Tulis Bakaran Juwana Pati, sehingga cakupan dalam penelitian ini relatif sempit. Penelitian selanjutnya hendaknya mengambil sampel ditingkat yang lebih luas 
lagi seperti di Industri Batik Tulis di wilayah Jawa Tengah agar hasilnya bisa lebih kompleks dan dapat digeneralisasikan.

\section{KESIMPULAN}

Berdasarkan hasil pengujian hipotesis dan pembahasan hasil penelitian, maka kesimpulan dalam penelitian ini adalah:

1. Variabel Islamic quality of work life berpengaruh positif dan signifikan terhadap turnover intention pengrajin pada Industri Batik Tulis Bakaran Juwana Pati.

2. Variabel work family conflict berpengaruh negatif dan signifikan terhadap turnover intention pengrajin pada Industri Batik Tulis Bakaran Juwana Pati.

3. Variabel sistem kompensasiberpengaruh positif dan signifikan terhadap turnover intention pengrajin pada Industri Batik Tulis Bakaran Juwana Pati.

\section{SARAN}

Bagi pihak pemilik Industri Batik Tulis Bakaran Juwana Pati agar dapat memperhatikan dengan baik tentang pemberian kompensasi bagi seorang pengrajin. Diperhatikan dengan sungguh-sungguh mengenai seberapa kompensasi yang diberikan atas balas jasa dari tenaga yang dikeluarkan oleh pengrajin, sehingga bisa digunakan untuk memenuhi kebutuhan. Selain itu juga perlu diperbaiki mengenai keamanan kondisi, kesejahteraan dan kenyamanan seorang karyawan. Karena dalam Islam kesejahteraan dan kenyamanan atau sering disebut kualitas kehidupan kerja itu sangat penting untuk diperhatikan juga. Jika bisa membuat karyawan merasa dihargai dan disejahterakan maka kinerja juga akan meningkat. Selain kedua faktor tersebut, memperhatikan keluhan dan apa yang diinginkan karyawan itu juga sangat penting. Misal terlihat dari tidak bisa menyeimbangkan antara pekerjaan dan keluarga. Maka dalam hal ini, bagi pemilik industri Batik Tulis Bakaran Juwana Pati agar memberi kelonggaran sedikit untuk memahami masalah yang dihadapi karyawan tersebut akibat menanggung peran ganda khususnya karyawan wanita. Sehingga apabila kita sebagai pihak perusahaan ataupun suatu industri bisa memahami apa yang diinginkan seorang tenaga kerja, maka hal ini akan berdampak baik bagi kelangsungan perusahaan atau industri kita sendiri.

\section{DAFTAR PUSTAKA}

Arrafiqur Rahman. (2017). Kualitas Kehidupan Kerja: Suatu Tinjauan Literatur dan Pandangan dalam Konsep Islam, Jurnal Ilmiah Cano Ekonomos, Vol. 6, No. 1, Januari.

Al-Qur'an Surat At-Taubah Ayat 105, Al-Qur'an dan Terjemahannya, Lajnah Pentashihan Mushaf Al-Qur'an Kementerian Agama RI, Syamil Qur'an, Jakarta, 2010.

Al-Qur'an Surat At-Qashash Ayat 77, Al-Qur'an dan Terjemahannya, Lajnah Pentashihan Mushaf Al-Qur'an Kementerian Agama RI, Syamil Qur'an, Jakarta, 2010.

Al-Qur'an Surat At-Taubah Ayat 71, Al-Qur'an dan Terjemahannya, Lajnah Pentashihan Mushaf Al-Qur'an Kementerian Agama RI, Syamil Qur'an, Jakarta, 2010.

Al-Qur'an Surat Al-Kahfi Ayat 30, Al-Qur'an dan Terjemahannya, Lajnah Pentashihan Mushaf Al-Qur'an Kementerian Agama RI, Syamil Qur'an, Jakarta, 2010. 
Erwin Paulus dan Hery Winoto. (2015). Pengaruh Kompensasi dan Kepuasan Kerja terhadap Turnover Intention Studi Kasus pada PT Multi Abadi Sejahtera, Jurnal Ilmiah Manajemen Bisnis, Vol. 15, No. 20, Juli-Desember.

Fishbein, dkk. (1975). Belief, Attitude, Intention, and Behavior: An Introduction to the Theory and Research, Massachuusetts, Addison Wesley Publishing Company.

Fransiskus Billy Sandy. (2019). Pengaruh Kompensasi terhadap Turnover Intention yang Dimediasi oleh Organizational Commitment Karyawan PT IDX, Jurrnal Manajemen, Vol. 16, No. 1, Mei.

Ida Ayu Diah Wulandari dan I Gusti Ayudewi Andyani. (2016). Pengaruh Work Family onflict terhadap Turnover Intention melalui Mediasi Kepuasan Kerja pada Hotel Grand Inna Kuta, E-Jurnal Manajemen Unud, ISSN : 2302-8912 Vol. 5, No. 10.

Imam Ghozali. (2006). Aplikasi Analisis Multivariat dengan Program SPSS, Badan Penerbit Universitas Diponegoro, Semarang.

M. Quraish Shihab. (1998). Wawasan Al-Qur;an, Tafsir Maudhui, Atas Berbagai Persoalan Umat, Mizan, Bandung.

Nur Riqoh Fuaidah, dkk. (2018). Pengaruh Kompensasi Karyawan dan Lingkungan Kerja Karyawan terhadap Turnover Intention (Studi pada Karyawan Auto 2000 MalangSutoyo), Jurnal Administrasi Bisnis (JAB), Vol. 60, No. 2, Juli.

Wahibur Rokhman, (2013) Pengaruh Quality of Work Life terhadap Kepuasan Kerja, Komitmen Organisasi, Turnover Intention, dan Stress Kerja: Studi pada BMT di Kudus, Jurnal Equlibrium, Volume 1, No.2, Desember. 